\title{
眼球・頭部非固定における自動車運転時の有効視野計測 *
}

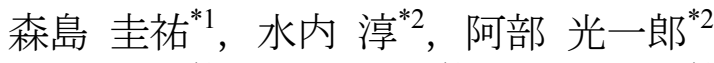 \\ 古木 翔"2, 山中 仁寛 ${ }^{* 3}$, 大本 浩司 ${ }^{* 1}$
}

\section{Measurement of Useful Field of View in Eye and Head-Free Condition while Driving}

\author{
Keisuke MORISHIMA, Atsushi MINOCHI, Koichirou ABE, \\ Sho FURUKI, Kimihiro YAMANAKA ${ }^{* 3}$ and Hiroshi DAIMOTO \\ ${ }^{* 3}$ Department of Management Systems Engineering, Tokyo Metropolitan University \\ 6-6 Asahigaoka, Hino, Tokyo, 191-0065 Japan
}

In this study, we conducted an experiment aimed at developing an effective method for measuring the useful field of view when driving while maintaining free visual (eye and head free) conditions with completely unobstructed head and eye movements. In the experiment, the mental workload was changed in a stepwise manner in order to test the hypothesis that the useful field of view becomes narrower as the mental workload (MWL) increases, as well as to verify the accuracy of the proposed method. The results confirmed the validity and accuracy of the proposed method for measuring the useful field of view under completely unobstructed visual conditions.

Key Words : Useful Field of View, Eye Tracking, High-Speed Camera, Head-Free Condition

\section{1. 緒言}

自動車を安全に運転するためにドライバーは, 常に視覚・聴覚等の感覚器で注意を喚起しなければならない. このうち視知覚は運転に必要な情報の最も多くを与えており, 交通事故のうち人身事故は実に $83 \%$ 范認知の欠如 と応答の遅れに由来していることが知られている(1) . そのため, 運転中のドライバーは見落としや不注意をなく 寸ため歩行者や信号等の適切な視対象を速く正確にとらえ, 知覚しなければならない(2).これらのことから, 運 転中にドライバーがどのように視対象をとらえ，どの程度の範囲において知覚しているか，つまり視覚探索方略 ならびに視対象の知覚範囲を理解することは, 運転作業の安全性向上や安全運転に関わる教育やサポートシステ ムの開発においても必要不可欠であるといえる.

運転中のドライバーの視覚探索方略に関する研究として, 三浦 ${ }^{(3)} \sim{ }^{(5)}$ は自動車運転時において, 道路の混雑状 況に応じて視線移動の頻度が異なるとの報告をしている．混雑度が高いほど注意深く状況を把握しなければなら ないために, 混雑した道路では視対象を知覚できる範囲が狭くなり, 視線移動の頻度が高くなるとともに停留時 間が短くなることを明らかにしている．また，Chapman ら(6)は，運転中の眼球運動を分析し，危険な状況での運 転ではドライバーはサッカードの移動量を小さくすることにより視覚探索領域を狭め, 停留時間を増大させるこ とにより視覚情報を収集する方策をとっていると報告している. Miltenburg ら(7)は, 運転走行中の視野画像を撮 影したビデオ画像を用いて被験者の交差点における眼球運動を調べ, 熟練者群のドライバーの眼球運動の停留は, 非熟練者群のドライバーに比較して簡潔に発生すると報告している.さらに, 瀬谷ら ${ }^{(8)}$ は, Miltenburg $ら^{(7)}$ の結果 は, 熟練者群が運転経験に基づく予測スキルの発達によって, 効率よく視対象の探索を行っているためと考察し

\footnotetext{
* 原稿受付 2013 年 3 月 19 日

*1 ヤマ八発動機 (株)

*2 首都大学東京 システムデザイン研究科

*3 正員, 首都大学東京 システムデザイン研究科（†191-0065 東京都日野市旭が丘 6-6）

E-mail: kiyamana@sd.tmu.ac.jp
} 
ている，一方，運転中のドライバーの視対象の知覚範囲に関する研究としては，有視視野の研究が相当する．有 効視野とは，視覚認知作業をするときに有効に活用されている視覚情報収集可能範囲のことである ${ }^{(9),(10)}$. 三浦に よる研究では, 実走行中にドライバーに提示した光点への反応と, 反応時のドライバーの視線位置から, 道路状 況が混雑すると有効視野が狭窄することを定性的に示唆している(5). また，有効視野領域の計測，評価法に関す る研究として，鈴木ら ${ }^{(1)}$ や児珠ら ${ }^{(12)}$ は，自動車運転時のドライバーに視覚的な負荷が増加した場合における視対 象の知覚可能範囲を, 視界を等領域に分割し, 有意に知覚率の高い範囲を求めることで計測している. その結果, 視覚的な負荷の増加に伴い有効視野が狭窄することを示している. また， Ball ら ${ }^{(13)}$, Owsley $ら^{(14)}$ とっても 視力やコントラスト感度といった基礎的な視機能と事故経験の関連性が有効視野領域の観点から検討されてきた が，それらの関連性は非常に低いことが示されている．しかしながら，これらの研究では，有効視野を予め円形 と定義し固視点からの半径を尺度とするものなど，視野の定義と計測・評価法が精度良く得られているとは言い 難い. これらの研究のように, 固視点保持の状態で周辺視野領域に標的刺激を出現させ，これを認知できる領域 を有効視野として評価寸ることはきわめて難しく, 有効視野を定量的に精度良く計測できているものは少ない(13) （18). これに対し, 山中ら ${ }^{(19)}$ は注視点からの視対象までの距離を刺激の強度ととらえ, その距離における視対象 の検出確率を心理測定曲線を推定することで求める方法で定量的に視覚域を測定する方法を提案している.また, 瀬谷ら ${ }^{(20)}$, Nakayasuら ${ }^{(21)}$, 青木ら ${ }^{(22)}$ はドライビングシミュレータ(以下DS)による運転作業中のドライバーの視線 計測結果から注視点を求め, 山中ら ${ }^{(19)}$ の提案した方法で運転時の有効視野計測を行っている．その結果，運転作 業時の有効視野も従来と同様に水平方向で広い形状であることを示している. しかしながら，これらの研究は視 野領域が定量的に評価されているものの頭部を固定した状態での実験や眼球運動のみに着目した実験であり, 完 全自由視状態での有効視野を評価できているとは言い難い.

上記背景に鑑み，本研究では，眼球・頭部運動をそれぞれ計測することで実注視点を求め，眼球・頭部運動に 全く制限を課さない完全自由視（頭部非固定）の状態において，DS を用いた自動車運転中のドライバーの有効 視野計測法の提案を行う。また，有効視野の特性の違いが定性的に明らかにされている走行道路の混雑度の違い を題材として，完全自由視の状態において提案した計測法により定量的な有効視野範囲を計測し，定性的な知見 と提案手法による定量的な計測結果の整合性を確認することで，提案した有効視野計測法の妥当性を検証する. さらには，付加的な聴覚課題と有効視野の関係についても検討することを目的とする.

\section{2. 有効視野計測法}

\section{$2 \cdot 1$ 心理測定曲線に基づく有効視野計測法}

心理測定曲線で評価される刺激闇值を結んで形成される包絡線内の領野を有効視野と定義する．いま，図 1 に 示寸ように, 注視点 $\mathrm{S}_{1}$ から認知対象物 $\mathrm{S}_{2}$ への距離を $x$ とする. $x$ は刺激強度を表す心理物理量であり ${ }^{(23)}, x$ が小 さいほど刺激は強く $x$ が大きいほど弱い. このため, $x$ を小さい值から大きくするとき認知できなくなる值が存 在する．この認知できなくなる $x$ の值は，刺激闇值(stimulus threshold)であり，それを有効視野の縁と考える．こ の刺激間值と検出確率の間には関数関係が成立し，その関数を表す曲線は心理測定曲線と呼ばれ，図 2 に表すよ うな曲線になる ${ }^{(24)}$. ただし, 本研究では刺激強度を注視点 $\mathrm{S}_{1}$ から認知対象物 $\mathrm{S}_{2}$ までの距離と定義するため, 值 が大きくなるにつれて刺激が弱まることに注意する必要がある. そのため, 図 2 に表す縦軸は非検出確率を表す.

いま，図 3 に示寸ように固視点 $\mathrm{S}_{1}$ から各方位における心理測定曲線が得られるとき，それぞれの方位における刺激閾值 を結んだ包絡線によって得られる領域を本研究では有効視野(UFOV)と定義している. ここでの刺激閾值は，心理測定曲線 が刺激強度(ここでは注視点からの距離を引数とする非検出確率の累積分布関数であることより, 非検出確率を指定したと きの累積分布関数の逆関数で得られるパーセント点に相当している. 非検出確率が $50 \%$ の場合の刺激閾值は主観的等価值 (PSE)に相当し ${ }^{(25)}$, 特に断らない限り本研究の有効視野は各方位でのPSEからの包絡線によって形成される.

ところで，心理測定曲線は刺激強度(あるいは知覚閾值) $x$ の関数として次式で表すことができる.

$$
P=f(x)
$$

式(1)の左辺は確率であり, 一般に次式のような正規分布の累積分布関数による確率で与えられている(24). 
$P=\Phi(y)=\int_{-\infty}^{y} \phi(y) d y, \quad y=\frac{x-\mu_{x}}{\sigma_{x}}, \phi(y)=\frac{1}{\sqrt{2 \pi}} e^{-\frac{y^{2}}{2}}$

ここに, $\mu_{x}, \sigma_{x}$ は $x$ の平均と標準偏差を表し $, \phi(・), \Phi(・)$ は正規分布の確率密度関数と累積分布関数である. 本研究では，実験において一組の変化刺激 $\left(x_{1}, x_{2}, \ldots\right)$ を用意しておき確率的に一つずつ提示する恒常刺激法 ${ }^{(18)}$ を用いる.このため, 注視点 $\mathrm{S}_{1}$ から認知対象物 $\mathrm{S}_{2}$ までの距離 $x$ を変化させて 2 件法(24)による“検知できる”もしく は“検知できない”反応を被験者の持つ押しボタン情報として記録する．なお，本研究では視対象を検出できる範 囲を有効視野と定義している。この記録から図 2 のように心理測定曲線を描くことは，実際には式(2)の確率分布 のパラメータを推定することである. 本研究では, 次節に示すプロビット法(26) によりパラメータを推定する.

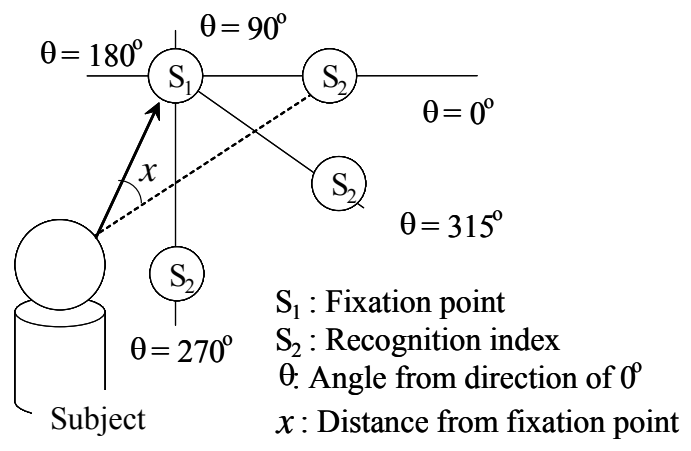

Fig.1 Distance and angles of recognition index

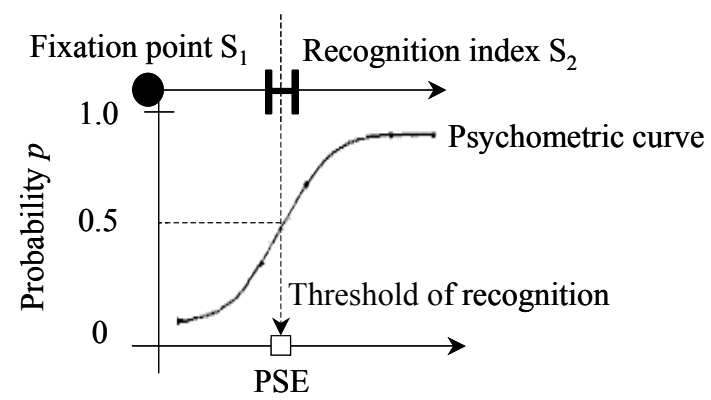

Distance form fixation point $X$ (Strength of stimuli)

Fig.2 Psychometric curve

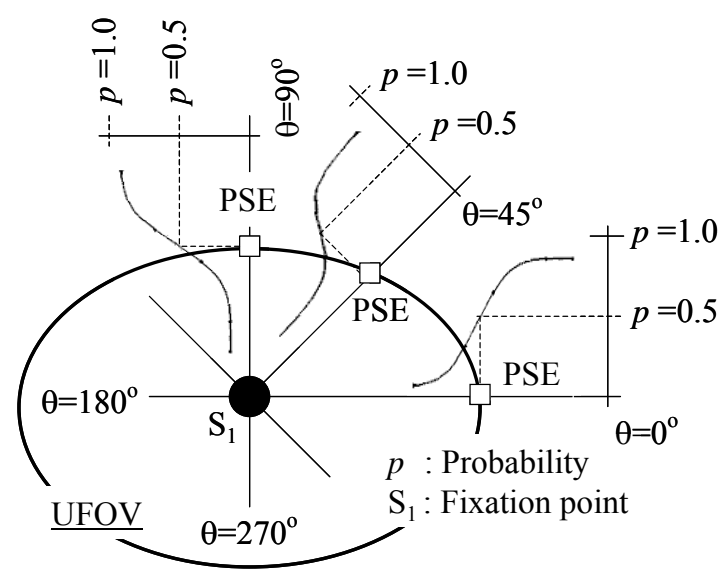

Fig.3 Definition of UFOV

\section{$2 \cdot 2$ プロビット法によるパラメータ推定}

図 3 に示すように, 固視点 $\mathrm{S}_{1}$ から角度 $\theta$ の方位において, 認知対象物 $\mathrm{S}_{2}$ が出現する座標の $\mathrm{S}_{1}$ からの距離 $x$ を 刺激強度(刺激閾值)とする，プロビット法ではこの $x$ の值をあらかじめ $x_{1}, x_{2}, \ldots, x_{n}$ と定めておき， $x_{\mathrm{j}}(j=1,2, \ldots, n)$ に おいて $N_{j}$ 回ランダムに認知対象物 $\mathrm{S}_{2}$ を示す。このとき, “認知できない”と反応した回数を $n_{j}$ と表すと, $x_{j}$ のとき に“認知できない”確率(非検出確率)の観測值である実測出現率 $p_{j}$ は $p_{j}=n_{j} / N_{j}(j=1,2, \ldots, n)$ と定義できる. 反応は 2 種類のみの反応カテゴリーなので, 実現值としての頻数の組み $\left(n_{1}, n_{2}, \ldots, n_{n}\right)$ が得られる確率は, 平均 $N_{j} p_{j}$ 分散 $N_{j} p_{j}$ $\left(1-p_{j}\right)$ の 2 項分布に従うものと考えると

$$
P\left(n_{1}, n_{2}, \ldots, n_{n}\right)=\prod_{j=1}^{n} \frac{N_{j} !}{n_{j} !\left(N_{j}-n_{j}\right) !} p_{j}{ }^{n_{j}}\left(1-p_{j}\right)^{N_{j}-n_{j}}
$$

と表すことができる。上式において， $p_{j}$ は式(1)で定義した確率 $P$ の実測值確率とみなすことができる. 知覚心理 学等の分野では $P$ を式(2)に示したような正規分布の累積分布関数による確率で与えている. そのため, 実測值確 
率 $p_{j}$ が得られたとき, これらのデータより母集団分布のパラメータ推定は以下に示すような最尤推定法で行われ る.

これより, 実測出現率 $p_{j}$ に対応する正規偏差 $y_{j}$ は正規分布する変量 $x$ と直線関係を示し, その推定值は定数 $a$, $b$ により

$$
\hat{y}_{j}=a+b x_{j}
$$

を当てはめ, そこから逆に

$$
\hat{y}_{j}=\Phi^{-1}\left(P_{j}\right)
$$

の関係を使って理論確率 $P_{j}$ を求める. $\Phi^{-1}$ は標準正規分布の累積分布関数の逆関数を表す.

$$
P_{j}=\Phi\left(a+b x_{j}\right)
$$

この理論確率 $P_{j}$ がパラメータ $a, b$ の関数で表されるので, 式(6)における正規分布関数のパラメータ推定は式(3) を尤度関数とする最尤法で求められる. すなわち最尤推定法であるので,

$$
l(a, b)=\sum_{j=1}^{n} \log \frac{N_{j}}{n_{j} !\left(N_{j}-n_{j}\right) !}+\sum_{j=1}^{n} n_{j} \log P_{j}+\sum_{j=1}^{n}\left(N_{j}-n_{j}\right) \log \left(1-P_{j}\right)
$$

を用いて求める. このとき，式(7)を $a, b$ で偏微分した式を零とおいた連立方程式の解は最尤推定量になる. そ のため, ニュートン法により次式の漸化式を用いるアルゴリズム(27)で繰り返し計算をして, 収束解として解く. この収束解は最尤推定量になる.

$$
\left[\begin{array}{l}
a \\
b
\end{array}\right]_{k+1}=\left[\begin{array}{l}
a \\
b
\end{array}\right]_{k}+\left[\begin{array}{cc}
\frac{\partial^{2} l}{\partial a^{2}} & \frac{\partial^{2} l}{\partial a \partial b} \\
\frac{\partial^{2} l}{\partial a \partial b} & \frac{\partial^{2} l}{\partial b^{2}}
\end{array}\right]_{k}^{-1}\left[\begin{array}{l}
\frac{\partial l}{\partial a} \\
\frac{\partial l}{\partial b}
\end{array}\right]_{k}
$$

ここに添字 $k$ は逐次計算の次数を表す. 式(8)の $a, b$ を $k$ 次の值から $k+1$ 次の值に更新する過程で, 新しい正規 偏差の候補として次式による仮の正規偏差 $y_{w k}$ を用いる(24).この方法は，正規偏差で表現すると直線になる性質 を利用して，更新時の新しい正規偏差の候補として式(9)による仮の正規偏差 $y_{w k}$ (これをプロビットと呼ぶ）を 用いて直線を当てはめるため, プロビット法と呼ばれている.

$$
y_{w k j}=\hat{y}_{k j}+\frac{1}{\phi\left(\hat{y}_{k j}\right)}\left(\hat{p}_{j}-P_{k j}\right)
$$

ここに， $\hat{y}_{k j}$ は $k$ 次の計算中に当てはめた直線の式(4)から読みとった正規偏差を表している. かくて， $k$ 次の $a$, $b$ の值と $k+1$ 次の $a, b$ の值の差が収束条件を満たしたときの $a, b$ の值が最尤推定值となる.

\section{3. 眼球・頭部運動計測からの実注視点算出法}

本研究では，頭部非固定での有効視野を計測するため，眼球のみならず頭部運動も考慮した実注視点の算出が 必要となる. そのため, 眼球, 頭部運動をそれぞれ独立に計測し, 得られた各回転角から実注視点を求める. 図 4 に実注視点算出の概要を示す. 図に示すように, 実験で視標を提示するDS の前方スクリーンの中心を初期点 $f_{0}$, ある時間 $t$ における眼球回転角 $e$ と頭部回転角 $h$ により得られる注視点がそれぞれ $f_{e}, f_{h t}$ とすると, その和が 実注視点 $f_{\text {eht }}$ となる. なお, 本研究での眼球運動計測における注視点の定義は, 左右眼それぞれで計測した注視点 の平均值としている. 眼球運動計測により得られる注視点座標は頭部の向きに依存することに注意が必要である. つまり，眼球運動計測により得られる注視点は常にローカル座標上の注視点となる．例えば，実際のある視対象 を注視している状態で頭部が運動した場合には，眼球の注視点はローカル座標上において頭部の運動と逆方向に 同じ距離だけ動いたとして計測される. そのため, グローバル座標における実注視点の算出は, 本研究で行うよ うに眼球と頭部運動の和により実施する必要がある. 眼球, 頭部それぞれの回転角の算出については, 事前に図 4 中に示すように初期点から垂直方向に上下 $8.7^{\circ}$ ，水平方向に左右 $21.1^{\circ}$ 間隔で設置した DS $の$ 前方スクリーン 
上の 9 点に対してキャリブレーションを実施し，あらかじめ被験者毎に実際の回転角あたりの取得データの変化 量を求めておくことで $f_{e t}, f_{h t}$ をそれぞれ算出する.

眼球運動の回転角の算出には視線計測装置(SR Research，Eye Link 2)を用いる。この装置における眼球運動計測 の測定可能範囲は水平方向で $\pm 30^{\circ}$ ，垂直方向で $\pm 20^{\circ}$, 計測誤差は $0.5^{\circ}$ ，空間分解能は $0.1^{\circ}$ である. 本研究 では，DS 前方のスクリーン上の各キャリブレーション点を注視している際の視線計測装置による取得データと 初期点を注視している際の取得データの変化量から垂直，水平の各成分における単位距離あたりの回転角度を算 出することで視線計測装置による眼球運動の回転角の算出を実現する．ただし，この場合の注視行動は眼球運動 のみで実施し，頭部は固定の状態とする，具体的には，本研究で用いた眼球運動計測装置により測定された眼球 回転角は，データレコーダに電圧值として記録される. 図 4 に示寸各キャリブレーション点を注視している場合 の電圧值をそれぞれ $\left(x_{1}, y_{1}\right),\left(x_{2}, y_{2}\right), \ldots,\left(x_{8}, y_{8}\right)$ とすると各キャリブレーション点での值と画面中心の初期点を注 視している場合の電圧值 $\left(x_{0}, y_{0}\right)$ の差が水平 $21.1^{\circ}$, 垂直 $8.7^{\circ}$ の眼球運動における電圧值の変化量となる. そのた め, $1^{\circ}$ の眼球運動における水平, 垂直方向での電圧值の変化量 $\Delta x, \Delta y$ は次式により求めることができる.

$$
\begin{aligned}
& \Delta x=\frac{\left|x_{0}-x_{1}\right|+\sum_{i=3}^{6}\left|x_{0}-x_{i}\right|+\left|x_{0}-x_{8}\right|}{6 \bullet 21.1} \\
& \Delta y=\frac{\sum_{i=1}^{3}\left|y_{0}-y_{i}\right|+\sum_{i=6}^{8}\left|y_{0}-y_{i}\right|}{6 \bullet 8.7}
\end{aligned}
$$

ある時間における眼球回転角は，水平，垂直方向それぞれにおいて，その時点における電圧值と画面中心の初期 点を注視している場合の電圧值の差分をとり, それを式(10), (11)により得られた $\Delta x, \Delta y に よ り$ 除算することに より求める.

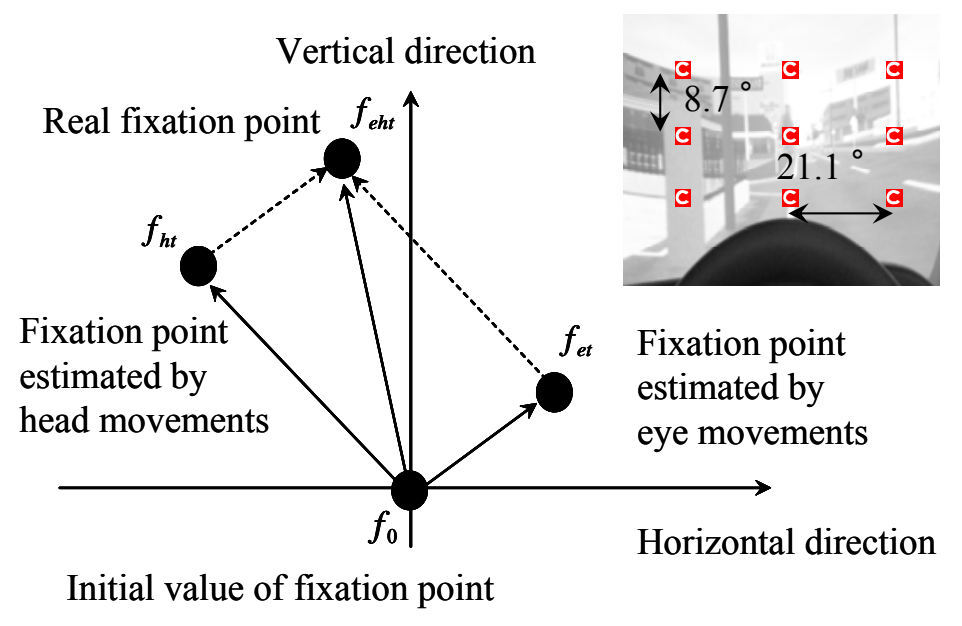

Fig.4 Image of real fixation point

次に, 頭部運動の回転角の算出法について述べる. 従来, 頭部運動の計測では, 頭部に 3 点のマーカーを設置 することで形成された三角形を 2 台のカメラにより撮影し，マーカーの位置関係を三次元空間上の点に変換する ことで頭部の回転角を算出寸る手法が一般的である ${ }^{(28)}$. 本研究では眼球, 頭部運動を同じデータレコーダに $250 \mathrm{~Hz}$ のサンプリングレートで計測するため，頭部に設置したマーカーの撮影には八イスピードカメラを用いるが，高 サンプリングレート条件においてはハイスピードカメラにより撮影できる解像度が非常に小さくなり $(640 \times 480)$, マーカーで形成する三角形も小さくなることで, 三次元空間座標に変換する過程で大きな誤差を生んでしまう. そこで，平面座標のみから頭部回転角を算出する手法の提案を行い，本実験にこれを適用する．図 5 に示すよう に, 被験者の後頭部に白色の紙粘土製の 5 つの球体を黒色のアクリル板上に $\mathrm{T}$ 字型に配置して作成したマーカー を設置する。このマーカーを被験者の背面よりハイスピードカメラで撮影し，空間上の初期点を注視している場 合の平面座標点と空間上のある点を注視している場合の平面座標点の変化量から頭部の回転角度を算出する.こ こで，平面座標点はハイスピードカメラにより撮影した画像からピクセル值による座標点として輝度差分により 
画像処理で抽出する．提案する頭部運動計測の精度を検証するため，図 6 に示すようなダミーヘッドに T 字型マ 一カーを取り付け, これをハイスピードカメラ(degimo, VCC-H1600)により後方より撮影し, 水平, 垂直方向に $\pm 30^{\circ}$ 回転させた時の頭部運動を正確に計測できているかの確認を行った．まず，ダミーヘッドが正面を向いて いる時の $\mathrm{T}$ 字型マーカーを記録し，水平，垂直方向に $\pm 10^{\circ}$ ずつ頭部を回転させた状態での $\mathrm{T}$ 字型マーカーも記

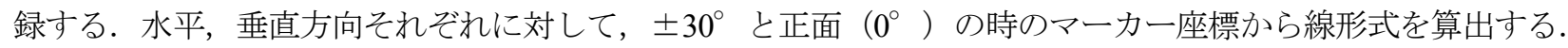
なお，線形式の算出に用いるマーカー座標值は 5 つのマーカー座標值の平均值である. 得られた線形式の \pm 10 , $20^{\circ}$ の值と実際にダミーヘッドを $10 ， 20^{\circ}$ 回転させたときの值を比較することで頭部運動計測の精度を検証す る. 図 7 に水平, 垂直方向それぞれにおけるダミーヘッドの回転角とマーカーの座標值の関係を示寸. 図中, 黒 いプロットは線形式を求めるための頭部が $\pm 30^{\circ}$ と正面（ $0^{\circ} ）$ の時のマーカー座標であり，白いプロットは頭 部が $\pm 10,20^{\circ}$ の時のマーカー座標を示す. 図より, 水平, 垂直方向のいずれにおいても, 頭部が士 $10,20^{\circ}$ の 時のマーカー座標が求めた線形式と一致している事が良くわかる. それぞれの方向における誤差の平均は, 水平 方向で $0.35^{\circ}$, 垂直方向で $0.14^{\circ}$ と非常に小さいものであった. なお, 空間分解能は $0.28^{\circ}$ である.
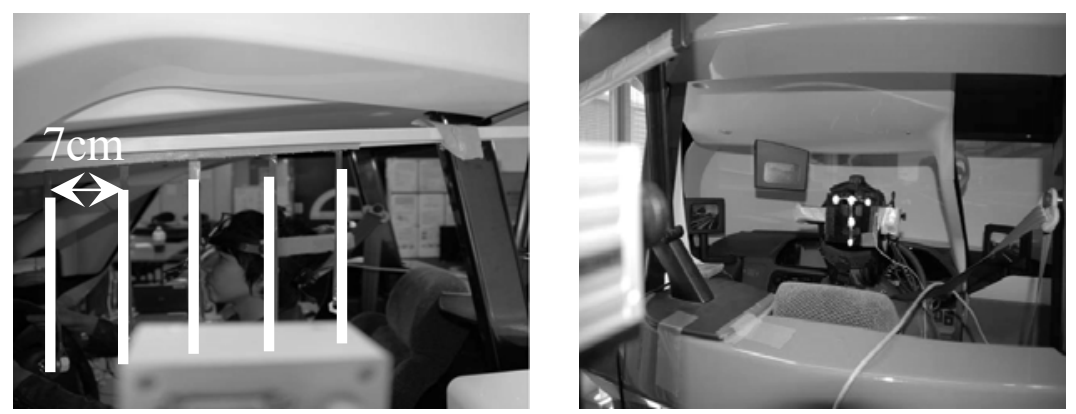

Fig.5 Snap shot by Hi-speed cameras

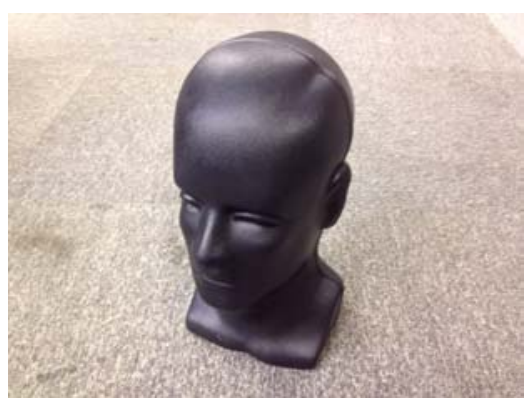

Fig.6 Dummy head

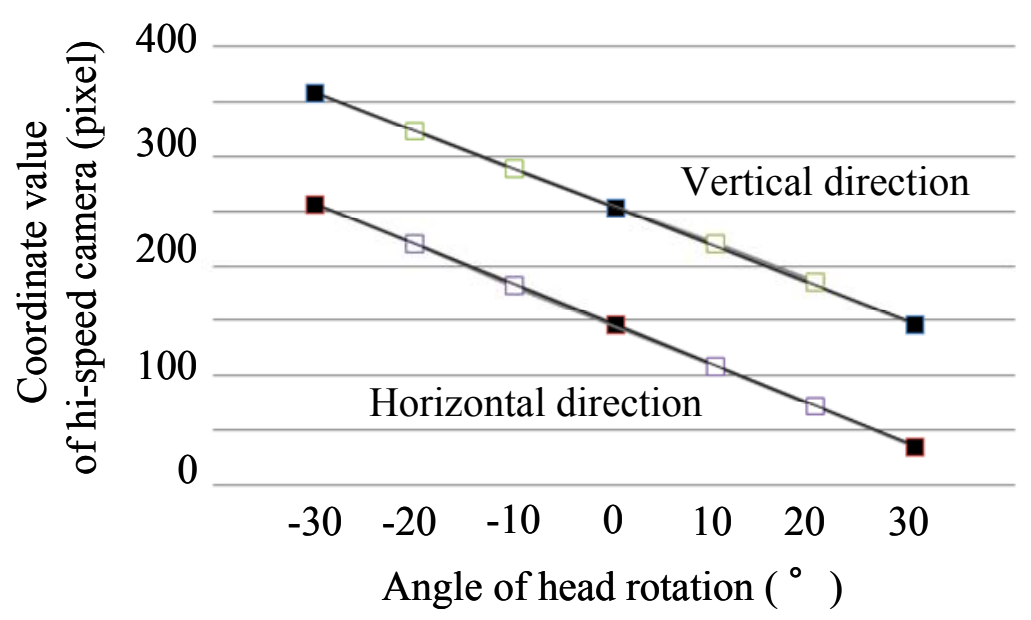

Fig.7 Verification result by dummy head 
また，眼球運動計測の誤差が用いた装置の仕様で $0.5^{\circ}$ であることと合わせて考えると，提案手法を組み合わ せて計測される実注視点の平均的な誤差は水平方向で $0.85^{\circ}$ ，垂直方向で $0.64^{\circ}$ となり，いずれにおいても $1^{\circ}$ 未満となることから, 提案手法の精度は妥当なものであると考える.

そこで, 提案手法の本研究への適用を行う. 本研究では, 八イスピードカメラを用いた撮影により得られるDS 前方のスクリーン上の各キャリブレーション点を注視している場合の平面座標点と初期点を注視している場合の 平面座標点の変化量から垂直，水平の各成分における単位距離あたりの回転角度を算出する．ただし，この場合 の注視行動は頭部運動のみで実施する. 図 8 に初期点, 左上のキャリブレーション点を注視している際の $\mathrm{T}$ 字型 のマーカー座標点を示す．図中黒色のプロットは初期点を，白色のプロットは左上のキャリブレーション点を注 視している際のマーカーの位置である. $\mathrm{T}$ 字型のマーカーに設置された 5 つの球体の座標点それぞれにおいて, 各キャリブレーション点と初期点を注視している際の差を水平, 垂直方向の変化量として扱う. 式(8), (9)より, $1^{\circ}$ の頭部運動における水平, 垂直方向でのピクセル值の変化量 $\Delta x, \Delta y$ を 5 つのマーカーそれぞれに対して求め, 平均をとることで，眼球回転角と同様に，ある時間における頭部回転角を算出する.

なお，この頭部回転角の算出は，平面座標点による回転角度の算出のため，垂直，水平方向の動きに関しては 対応できるが，前後の動きについては対応ができない，そのため，被験者の側面からハイスピードカメラによる 撮影をすることで, 被験者の前後移動量から頭部回転角の補正を行えるようにする. 実験に使用する DS は, 被 験者眼前から前方スクリーンまでの距離が $150 \mathrm{~cm}$ であり，頭部の前後移動量が $7 \mathrm{~cm}$ 以上発生すると DS の前方ス クリーン上では視野角にして $1^{\circ}$ のずれが生じる. そのため, 被験者と側面の八イスピードカメラとの間に図 5 に示寸通り $7 \mathrm{~cm}$ 間隔で領域を区切ることで, 被験者の頭部が $7 \mathrm{~cm}$ 以上前後に移動した場合は頭部回転角から $\pm 1^{\circ}$ の補正を行う。また，上下，左右方向への平行運動については，事前に数回実施した予備試験においてほとんど 確認できなかったため, 本研究においては補正の必要はないと判断する.

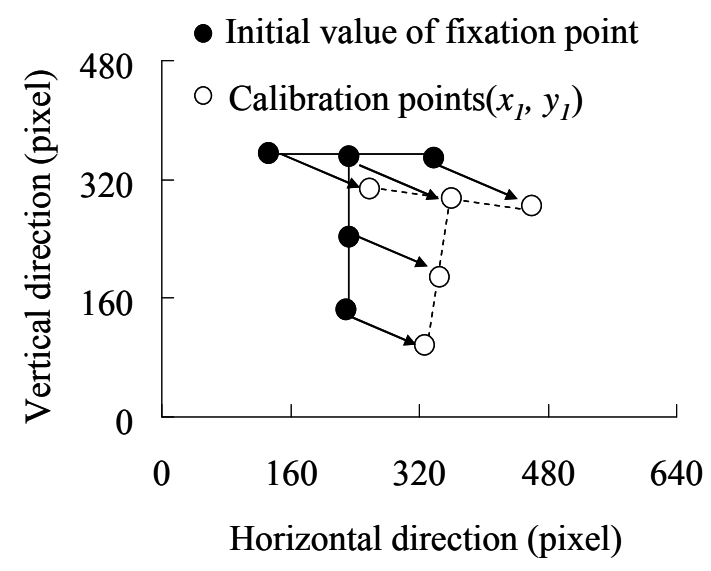

Fig.8 Variation of coordinate with head movement.

\section{4. 提案手法を用いた有効視野計測実験}

\section{$4 \cdot 1$ 被験者}

被験者は, 21 25 歳(平均 22.9 歳, 標準偏差 1.05 歳)の運転免許証を所有している健康な男子学生 9 名とし, 実験内容について十分な説明を行い，書面にて同意を得てから実験を行う。なお，被験者を実験で使用する DS での走行に慣熟させるため，被験者に実験前日までにDS での練習コース走行を課し，習熟を確認する.

\section{$4 \cdot 2$ 実験デザインおよび手順}

本実験は，DS（HONDA，DA-01）により実施した。図 9 に実験機器構成のブロック図を示す。被験者には視 線計測装置(SR Research， Eye Link 2)を装着し，角膜反射法により眼球運動を，DS の運転席後方ならび側方に被 験者からの距離 $60 \mathrm{~cm}$ の位置に設置したハイスピードカメラ (degimo, VCC-H1600) により頭部運動を計測する. 被験者眼前における輝度は $62.67 \mathrm{~cd} / \mathrm{m}^{2}$, 照度は $491.31 \mathrm{x}$ である. 被験者は完全自由視状態で DS の運転作業を遂行 
し，DS スクリーン上に 3 秒間隔で 2 秒間出現する検出視標にハンドルに取り付けたボタンで応答する. 検出視 標の形状は赤色背景に白抜きのランドルト環形状であり, サイズは視角にして 1 ○する. 先行研究(19)を参考に, この反応課題の成績を用いて有効視野の計測を行う。具体的には注視点から視標までの距離を刺激の強度とし, 検出確率からプロビット法により心理測定曲線を推定し, 検出確率 50\%点(主観的等価值:PSE)を有効視野の縁と 定義する．なお，本実験では DS の視標表示領域が垂直方向で狭いため，十分な広さを確保でき精度の良い視野 領域の計測が可能である水平方向の有効視野のみを計測する. 具体的には，検出視標出現時の注視点に対して左 右いずれかの水平方向（注視点右水平方向を $0^{\circ}$ とし，反時計回りに角度を割り当てた場合の $0 \sim 15^{\circ}, 165 \sim 195^{\circ}$, 345 360）に検出視標が出現した場合のデータで有効視野を算出する. 同時に検出視標が提示されてから被験者 のボタン押しによる応答までの時間も応答時間として記録する.なお，被験者の眼球，頭部運動と視覚刺激への

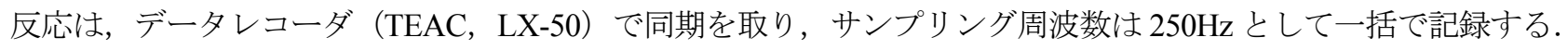

また, 被験者には副次課題 (MWL 課題) として, 先行研究(29)を参考に「読み上げ」,「加算」の数的課題を課 す. 実験条件は数的課題を行わない「なし」条件を加えた 3 条件（なし，読み上げ，加算）とする.この数的課 題は，誘発電位との同時計測により MWLの定量化がすでに行われており，負荷の低いものから，「なし」，「読み 上げ」,「加算」である. 課題の内容は, 一桁の数值が音声ソフトにより被験者に伝えられ, 被験者がその数值を復 唱する課題を「読み上げ」, 連続する 2 つ数值を加算し答えの一桁目のみを回答する課題を「加算」とする. な お，数的課題に対する正答率も評価指標として記録する.

さらに，各注視点における課題要件の違い，すなわち視覚的な負荷の違いについても検討するため，被験者が 走行するコースとして, 他車両が存在し混雑度が高い市街地を模した「市街地コース」と, 他車両が存在せず混 雑度の低い単純な周回走行を繰り返す「周回コース」の 2 条件を設定する. 走行するコースについては，図 10 に前方映像の一例とともに示すものである．走行は，両コース共に一般的に自動車教習所での危険予測教習にあ るような歩行者の飛び出し，二輪車の巻き込み等の事故を誘発するような危険イベントを除いたものとする．被 験者には，速度制限を $40 \mathrm{~km} / \mathrm{h}$ とし，交通法規を遵守した運転を行うよう教示する，以上より，実験条件は MWL 課題 3 条件，コース条件 2 条件の計 6 条件である. それぞれの走行後に被験者に NASA-TLXへの回答を求め, 主観的評価指標とする. なお, 被験者には課題遂行の優先度が, DS の運転課題, 視標検出課題, MWL 課題の順 であることを教示する。

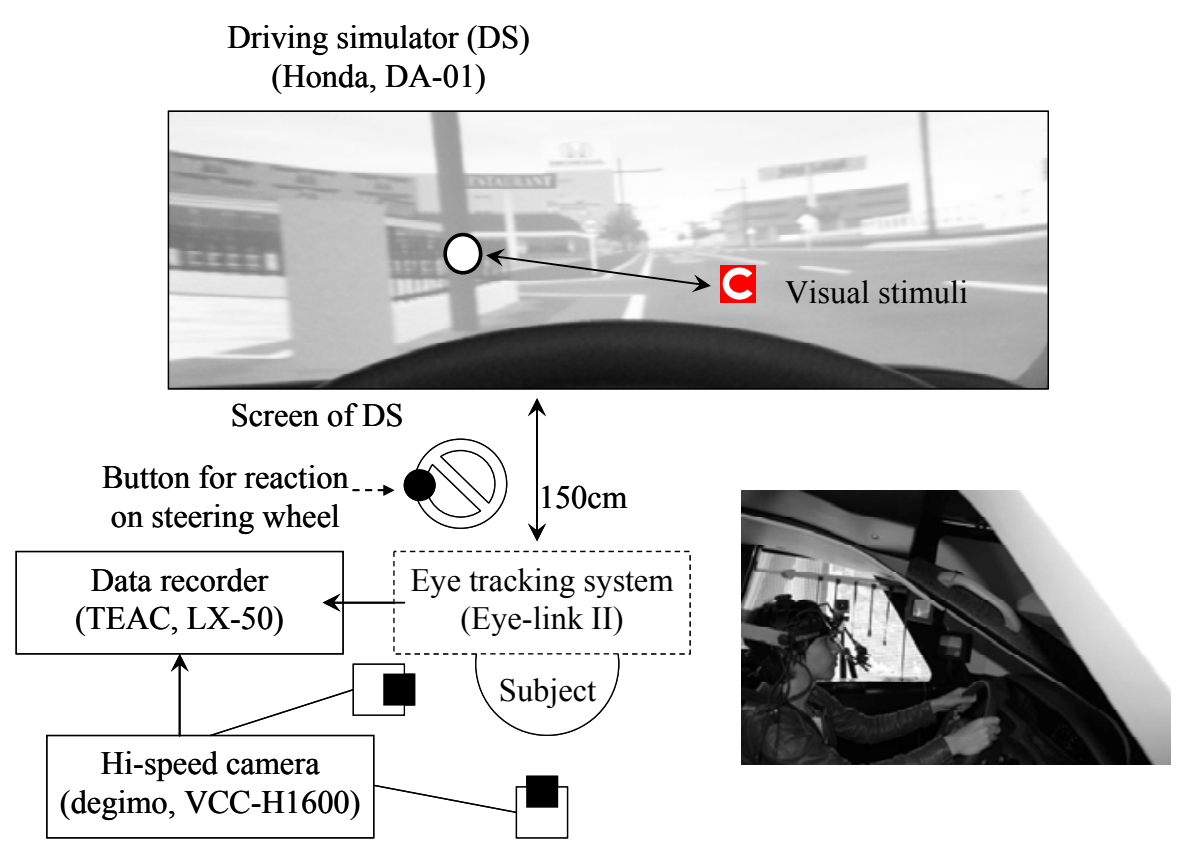

Fig.9 Experimental layout 


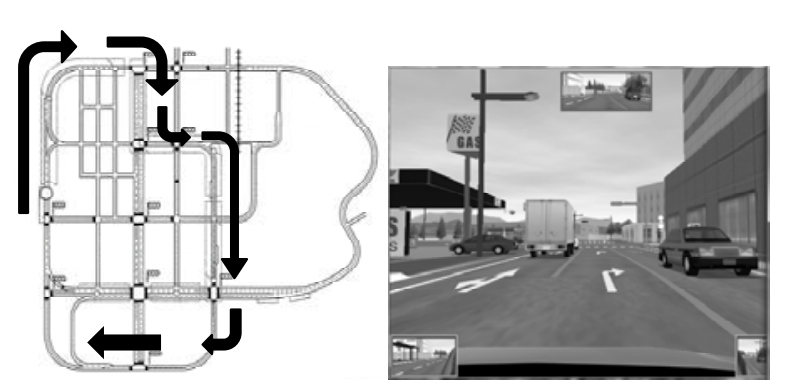

(a) Course of crowded (Urban)

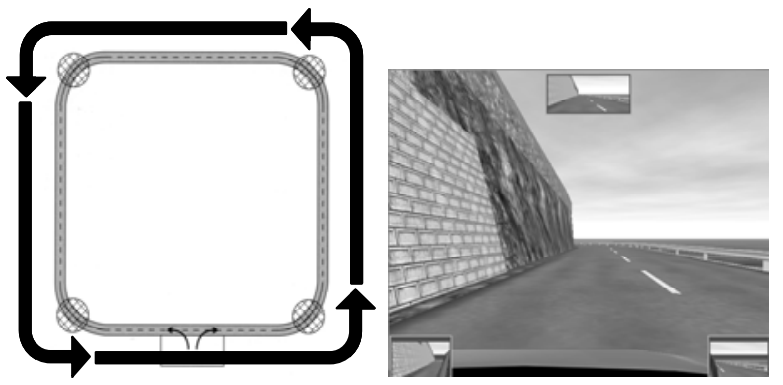

(b) Course of non-crowded (Loop)

Fig.10 Route of driving and snapshot of driving movie

\section{$4 \cdot 3$ 実験結果と考察}

図 11 に数的課題に対する正答率を示す. 図のように, 読み上げ条件のほぼ $100 \%$ に対して, 加算条件では約 $80 \%$ であった．正答率を特性值とし，コース（市街地，周回）と数的課題（読み上げ，加算）を要因とした 2 元配置 分散分析を行ったところ, 表 1 に示寸とおり両要因ともに主効果 $(\mathrm{p}<0.01)$, 交互作用 $(\mathrm{p}<0.01)$ が認められた. さらに下位検定の結果，コース難易度が高くなる市街地では周回に比べて読み上げ条件 ( $<<0.05, \mathrm{t}$ 検定), 加算 条件（p $<0.01, \mathrm{t}$ 検定）とも正答率が低下寸る結果であった．また，それぞれのコース内においても，加算条件で 読み上げ条件に比べて正答率が低下寸る結果であった $(\mathrm{p}<0.01, \mathrm{t}$ 検定)。この結果から, 数的課題とコース条件 の両方がドライバーに対して負荷となっていることがわかる.

そこで, 各要因がドライバーへ与える負荷の大きさを確認するため, 主観的評価指標として採用した NASA-TLX に対する回答を用いて算出した AWWL 得点 ${ }^{(30)}$, ならびに視標検出課題に対する応答時間を用いて, 検討を行う. 図 12 に AWWL 得点, 図 13 に視標検出課題に対する反応時間を示寸. それぞれの図の值について も, コース（市街地，周回）と数的課題（なし，読み上げ，加算）を要因とした 2 元配置分散分析を行った. 結 果, 表 2, 3 に示寸とおり AWWL 得点, 反応時間とも, 両要因に主効果（p<0.01）が認められ, コースについて は, 市街地で負荷が増大する結果であった. さらに, 数的課題については, 多重比較検定の結果, なし条件と加 算条件, 読み上げ条件と加算条件で有意な差が認められた（いずれも $\mathrm{p}<0.05, \mathrm{Holm}$ ). なお, 以下に示す有効視 野の分析についても同様の手続きとした.

図 14 に, 有効視野計測の結果を示寸. 計測された有効視野は加算条件で最も狭窄し, 読み上げ条件, なし条件 の順に大きくなる結果であった。 ここでも，表 4 に示すとおり，コース（p<0.05), 数的課題 $(\mathrm{p}<0.01)$ ともに主 効果が認められ，周回に比べ市街地で有意に有効視野が狭窄することがわかった．数的課題については，多重比 較検定の結果, なし条件と加算条件, 読み上げ条件と加算条件で有意な差が認められた (いずれも $\mathrm{p}<0.05, \mathrm{Holm}$ ). この結果は，MWL が大きくなると有効視野が狭窄することを示しており，加算条件のように負荷が大きくなる と有効視野の狭窄が顕著になることがわかる.

上記いずれの結果も, 数的課題なし条件と加算条件, 読み上げ条件と加算条件間で有意な差が認められる関係 となっており，全ての結果で整合性があるといえる.しかしながら，数的課題を用いた先行研究(29)では「なし」 と「読み上げ」条件間にも差があると報告されているが, 本研究の結果では「なし」と「読み上げ」間には AWWL 得点, 応答時間, 有効視野で統計的な差はみられなかった. これについて考察を行う. 本研究において被験者が 最も優先する課題は運転課題であるが，実験概要でも述べた通り運転課題は危険イベント等を除いた非常に安全

（容易）な課題であったと考えられる. 図 11 に示した数的課題の正答率でも「読み上げ」条件では，ほぼ $100 \%$ と被験者にとって非常に小さな負荷であったといえる. そのため, AWWL 得点でも差がみられなかったと考え られる．また，運転課題が非常に容易であったことから小さな負荷である「読み上げ」条件では有効視野の狭窄 が起こらず視野内の視覚対象物への応答である応答時間にも差がみられなかったと考えられる.

次に, 本研究で提案した完全自由視状態での有効視野計測手法の妥当性について検討する. Miura ${ }^{(5)}$ が行った研 究では, 様々な道路条件（例えば, 混雑した道路や高速道路等）での実走行中に光点を提示し, その反応時間と 
Table 1 ANOVA table for ratio of correct answers

\begin{tabular}{|c|c|c|c|}
\hline Factors & Frequency & $\begin{array}{l}\text { Unbiased } \\
\text { variance }\end{array}$ & Variance ratio \\
\hline s & 8 & 0.0068 & \\
\hline A & 1 & 0.0215 & $20.92^{* *}$ \\
\hline $\mathrm{s} \times \mathrm{A}$ & 8 & 0.0010 & \\
\hline $\mathrm{B}$ & 1 & 0.2444 & $38.21^{* *}$ \\
\hline $\mathrm{s} \times \mathrm{B}$ & 8 & 0.0064 & \\
\hline $\mathrm{A} \times \mathrm{B}$ & 1 & 0.0184 & $18.83^{* *}$ \\
\hline $\mathrm{s} \times \mathrm{A} \times \mathrm{B}$ & 8 & 0.0010 & \\
\hline
\end{tabular}

A: Road environment

B: Mental workload

$\mathrm{A} \times \mathrm{B}$ : Interaction of $\mathrm{A}$ and $\mathrm{B}$

$\mathrm{s} \times \mathrm{A}$ : Nonsystematic error with $\mathrm{s}$ to $\mathrm{A}$

$\mathrm{s} \times \mathrm{B}$ : Nonsystematic error with $\mathrm{s}$ to $\mathrm{B}$

$\mathrm{s} \times \mathrm{A} \times \mathrm{B}:$ Nonsystematic error with $\mathrm{s}$ to $\mathrm{A} \times \mathrm{B}$
Table 2 ANOVA table for score of AWWL

\begin{tabular}{|c|c|c|c|}
\hline Factors & Frequency & $\begin{array}{l}\text { Unbiased } \\
\text { variance }\end{array}$ & Variance ratio \\
\hline s & 8 & 553.512 & \\
\hline A & 1 & 2016.554 & $35.02^{* *}$ \\
\hline $\mathrm{s} \times \mathrm{A}$ & 8 & 57.578 & \\
\hline $\mathrm{B}$ & 2 & 7329.426 & $28.48^{* *}$ \\
\hline $\mathrm{s} \times \mathrm{B}$ & 16 & 257.372 & \\
\hline $\mathrm{A} \times \mathrm{B}$ & 2 & 1.812 & 0.03 \\
\hline $\mathrm{s} \times \mathrm{A} \times \mathrm{B}$ & 16 & 52.335 & \\
\hline \multicolumn{4}{|c|}{$\begin{array}{l}\mathrm{s}: \text { Individual variation } \\
\mathrm{A}: \text { Road environment } \\
\mathrm{B}: \mathrm{p}<0.01 \\
\mathrm{~A} \times \mathrm{B}: \text { Interaction of A and } \mathrm{B} \\
\mathrm{s} \times \mathrm{A} \text { : Nonsystematic error with s to A } \\
\mathrm{s} \times \mathrm{B} \text { : Nonsystematic error with } \mathrm{s} \text { to } \mathrm{B} \\
\mathrm{s} \times \mathrm{A} \times \mathrm{B}: \text { Nonsystematic error with } \mathrm{s} \text { to } \mathrm{A} \times \mathrm{B}\end{array}$} \\
\hline
\end{tabular}

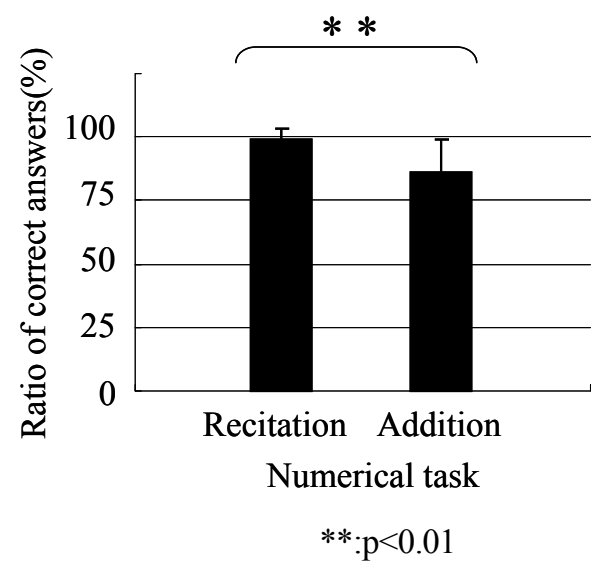

(b) Course of non-crowded

(a) Course of crowded

Fig.11 Mental workload and ratio of correct answers

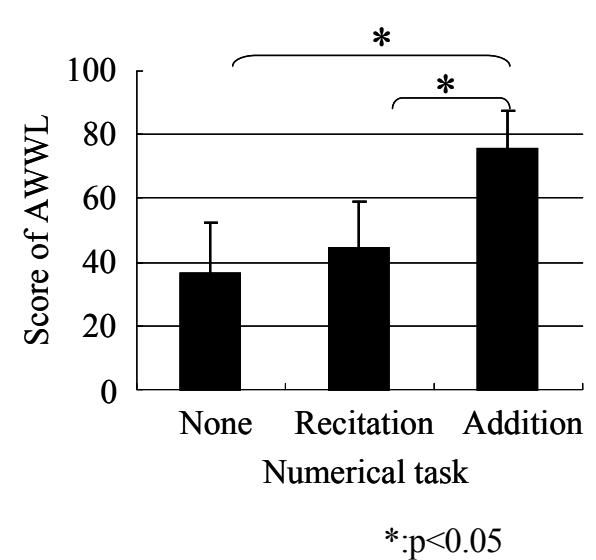

(a) Course of crowded

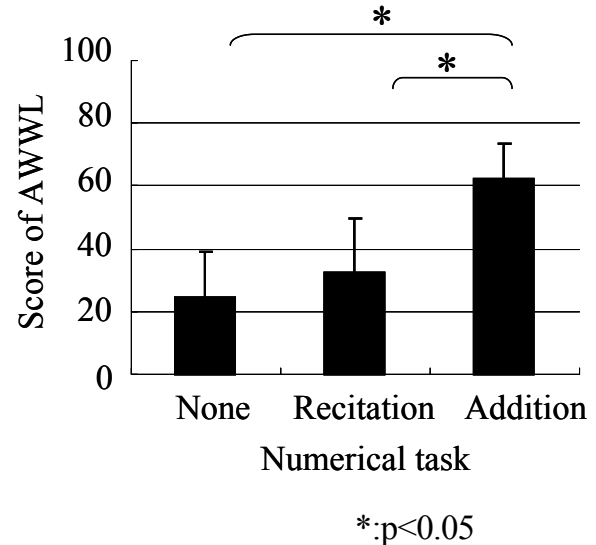

(b) Course of non-crowded

Fig.12 Mental workload and score of AWWL 
Table 3 ANOVA table for score of response time

\begin{tabular}{cccc} 
Factors & Frequency & $\begin{array}{c}\text { Unbiased } \\
\text { variance }\end{array}$ & Variance ratio \\
\hline s & 8 & 0.1751 & \\
\hline A & 1 & 0.2623 & $26.57^{* *}$ \\
s $\times$ A & 8 & 0.0099 & \\
\hdashline B & 2 & 0.6227 & $37.81^{* *}$ \\
s $\times$ B & 16 & 0.0224 & \\
\hdashline A $\times$ B & 2 & 0.0003 & 0.08 \\
s $\times$ A $\times$ B & 16 & 0.0037 & \\
s : Individual variation & \\
A: Road environment & \\
B: Mental workload & p $<0.01$ \\
A $\times$ B: Interaction of A and B \\
s $\times$ A: Nonsystematic error with s to A \\
s $\times$ B: Nonsystematic error with s to B \\
s $\times$ A $\times$ B : Nonsystematic erro with s to A $\times$ B
\end{tabular}

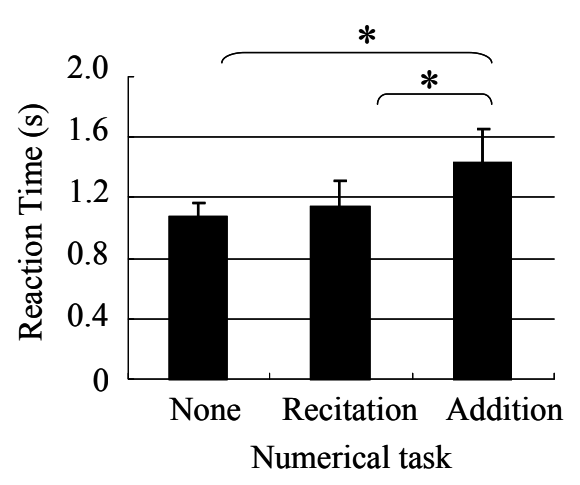

$*: \mathrm{p}<0.05$

(a) Course of crowded
Table 4 ANOVA table for useful field of view

\begin{tabular}{|c|c|c|c|}
\hline Factors & Frequency & $\begin{array}{l}\text { Unbiased } \\
\text { variance }\end{array}$ & Variance ratio \\
\hline s & 8 & 142.186 & \\
\hline A & 1 & 162.240 & $8.30^{*}$ \\
\hline $\mathrm{s} \times \mathrm{A}$ & 8 & 19.547 & \\
\hline B & 2 & 667.957 & $18.22^{* *}$ \\
\hline $\mathrm{s} \times \mathrm{B}$ & 16 & 36.656 & \\
\hline $\mathrm{A} \times \mathrm{B}$ & 2 & 20.889 & 0.72 \\
\hline $\mathrm{s} \times \mathrm{A} \times \mathrm{B}$ & 16 & 29.071 & \\
\hline $\begin{array}{l}\text { s: Individu } \\
\text { A: Road en } \\
\text { B: Mental w } \\
\text { A } \times \text { B: Inter } \\
\text { s } \times \text { A: Non } \\
\text { s } \times \text { B: Non } \\
\text { s } \times \text { A } \times \text { B : }\end{array}$ & $\begin{array}{l}\text { al variation } \\
\text { jironment } \\
\text { orkload } \\
\text { action of A an } \\
\text { systematic er } \\
\text { systematic er } \\
\text { Nonsystema }\end{array}$ & $\begin{array}{l}\text { nd } B \\
\text { rror with } \mathrm{s} \text { to } \\
\text { rror with } \mathrm{s} \text { to } \\
\text { tic error with }\end{array}$ & $\begin{array}{l}\mathrm{A} \\
\mathrm{B} \\
\mathrm{h} \text { s to } \mathrm{A} \times \mathrm{B}\end{array}$ \\
\hline
\end{tabular}

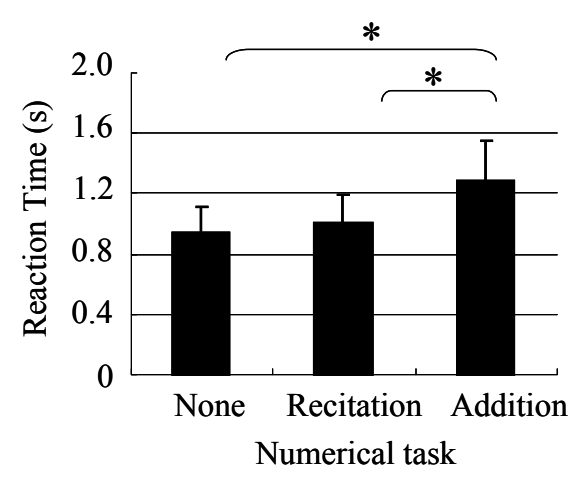

$*: \mathrm{p}<0.05$

(b) Course of non-crowded

Fig.13 Mental workload and response time

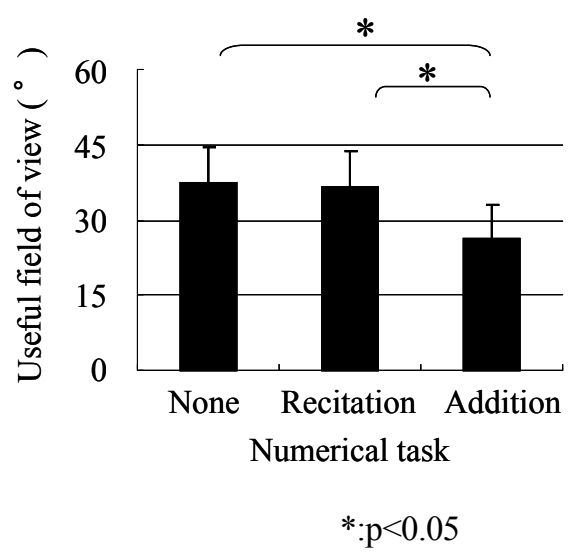

(a) Course of crowded

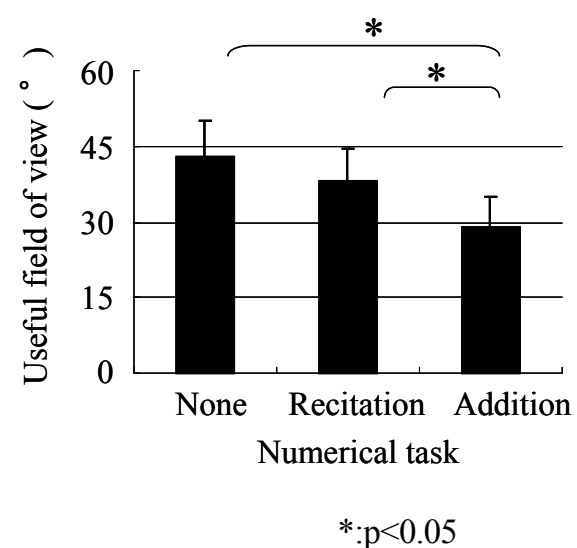

(b) Course of non-crowded

Fig.14 Mental workload and useful field of view 
視線位置を測定し，道路状況が混雑しているほど反応時間が遅くなり，また反応時の視線位置と光点との距離が 近くなることを示している，この結果は，道路状況が混雑するほど有効視野が狭くなるために，視線を光点付近 に移動させる必要があり, 反応時間も延長したと結論づけており，情報処理の資源一定則と情報処理の深さの仮 説から認知心理モデルを立てて視野狭窄現象を説明することに成功している ${ }^{(10)}$. これらのことは, 本研究で得ら れた周回コースに比べて市街地コースで視覚刺激への反応時間が延長し, 有効視野も狭窄する結果と一致してお り, 本研究で提案した眼球・頭部非固定での有効視野計測法の妥当性が高いことを示している. また, 本研究で 得られた結果は上記仮説の正当性を定量的に明らかにしたことにもなると考えられる.

次に, 数的課題による有效視野の狭窄について検討する.川村ら ${ }^{(31)}$ は視覚情報処理のみならず運転時の同乗者 との会話といった聴覚情報処理（中枢系での処理）量が増加すると有効視野が狭窄することを示している．この 結果についても, 本研究での数的課題によって有効視野が狭窄した結果と一致している.このことは, MWLが 増加すると運転行動以外に配分寸る処理資源量が増加寸ることから視覚的注意に配分できる処理資源量が減少し， 有効視野が狭窄することを示しており, MWL と有効視野の関係を定量的に示すことができた. さらに, 本研究 での有効視野の結果は, 数的課題に対する正答率や視標検出課題に対する反応時間, NASA-TLXの AWWL得点 の結果と同様の傾向を示しており, 全ての結果で整合性がとれたことからも MWL と有効視野には関係があるこ とがわかる.このことから, MWL を情報処理の負担度と考えれば, 有効視野はドライバーの情報処理の負担度 を評価しうる指標となる可能性があることを示唆した.

\section{5. 結 言}

本研究では，眼球，頭部運動に全く制限を課さない完全自由視（頭部非固定）の状態で，自動車運転中のドラ イバーの有効視野計測法の開発を試みた。 また, 走行道路の混雑度の違いを題材として, 提案手法による有効視 野計測の妥当性を検証すること, さらに付加的な聴覚課題と有効視野の関係についても検討することを目的とし, 実験を行った，得られた結果を要約し，次の 3 項目を本研究の結論とする.

1）眼球・頭部運動を同時に計測することで, 完全自由視（頭部非固定）状態での自動車運転中のドライバーの有 効視野を計測する手法を提案し，その有効性を実験的に明らかにした.

2）従来より提唱されている情報処理の深さと広さの関係を示した認知心理モデルの正当性を定量的に示した.

3) 有効視野は, 視覚のみならず他の感覚器より入力される全ての情報の処理量に影響を受けることから, ドライ バーをはじめとする作業者の情報処理の負担度を評価しうる指標となる可能性があることを示唆した.

\section{文献}

（1）藤森充，上迫宏計，川村幹也，“高速道路における頭部運動を考慮した運転者の視線計測”, 計測自動制御学会論文集, Vol.35, No.4 (1999), pp.473-479.

(2) Vivek, D. B., "Ergonomics in the automotive design process", CRC Press Taylor \& Francis Group, (2012), pp. 105-126.

(3) 三浦利章, “運転場面における視覚的行動 - 眼球運動の測定による接近 - ”, 大阪大学人間科学部紀要, Vol.3 (1979), pp.253-289.

(4) 三浦利章, “視覚的行動・注視時間と有効視野を中心として”, 大阪大学大学院人間科学研究科紀要, Vol. 8 (1982), pp.171-206.

(5) Miura, T., "Visual search in intersections - An underlying mechanism - ", International Association of Traffic and Safety Sciences Research, Vol.16, No.1 (1992), pp.42-49.

(6) Chapman, P. and Underwood, G., "Visual search of driving situations: Danger and experience", Perception, Vol.27 (1998), pp.951-964.

(7) Miltenburg, P. and Kuiken M., The effect of driving experience on visual search strategies: Results of a laboratory experiment, (1990), University of Groningen, Haren.

（8）瀬谷安弘，中易秀敏，三好哲也，“自動車運転作業時の眼球運動解析による視覚探索法略に関する研究”, 電子情報通 信学会技術研究報告. HIP, ヒューマン情報処理, Vol.107 ( 2007), pp.125-130. 
（9）苛阪良二，現代基礎心理学 3 知覚 II, (1982), pp.183-231, 東京大学出版会.

(10) 三浦利章, 行動と視覚的注意, (1996), pp.36-52, 風間書房.

(11) 鈴木雅寿, 近野淳一, 佐藤美恵, 長谷川光司, 春日正男, 阿山みよし, “自動車運転時の交差点区間における有効視野 の検討”, 映像情報メディア学会技術報告，Vol.30, No.42 (2006), pp.53-54.

(12) 児珠大輔, 目加田慶人, 阿山みよし, 春日正男, “視覚と会話負荷が自動車運転時の有効視野に与える影響”,映像情 報メディア学会技術報告, Vol.24, No.41 (2000), pp.7-12.

(13) Ball, K. and Owsley, C., "The useful field of view test: a new technique for evaluating age-related declines in visual function", Journal of the American Optometric Association, Vol.64, No.1 (1993), pp.71-79.

(14) Owsley, C., Ball, K. and Keeton, D. M., "Relationship between visual sensitivity and target localization in older adults", Vision Research, Vol.35, No.4 (1995), pp.579-587.

(15) Ikeda, M. and Takeuchi, T., "Influence of foveal load on the functional visual field", Perception \& Psychophysics, Vol.18, No.4 (1975), pp.255-260.

(16) 阿山みよし，松澤麻紀，目加田慶人，“動的背景上の有効視野に対する音声情報の影響照明学会誌”, Vol.85, No.2 (2001), pp.105-112.

(17) 三好哲也，中易秀敏，鈴木大介，“運転時の周辺視野眼球運動一の影響”, 人間工学, Vol.43, No.2 (2006), pp.97-100.

(18) Alan, H. S. and Chan, D. K. T., "Measurement and quantification of visual lobe shape characteristics", International Journal of Industrial Ergonomics, Vol.36 (2006), pp.541-552.

(19) 山中仁寛, 中易秀敏, 三好哲也, 前田多章, “視覚認知作業時の有効視野評価法に関する研究”, 日本機械学会論文集 C 編, Vol.72, No.719 (2006), pp244-252.

(20) 瀬谷安弘, 八木理, 中易秀敏, “リアルタイム視線移動解析による運転作業時の有効視野計測”, 電子情報通信学会技 術研究報告. MBE, ME とバイオサイバネティックス, Vol.107, No.460 (2008), pp.43-46.

(21) 中易秀敏, 青木大和, 三好哲也，中川雅央，“運転状況の変化に基づく運転作業者の知覚と認知特性の実験的分析”, 構造物の安全性及び信頼性 (JCOSSAR2011), Vol.6 (2011), pp.506-511.

(22) 青木大和, 中易秀敏, 三好哲也, “ドライバーの視線移動解析に基づく自動車運転時の知覚認知と信頼性”, 信頼性シ ンポジウム講演論文集, Vol.25 (2010), pp.124-129.

(23) 大山正, 今井省吾, 和気典二, 新編 感覚・知覚ハンドブック, (1994), pp.185-193, 誠心書房.

(24) 日科技連官能検査委員会, 新版・官能検査ハンドブック,(1999), pp.395-443, 日科技連出版社.

(25) 日本視覚学会編, 視覚情報処理ハンドブック,(2004), pp.563-571, 朝倉書店.

(26) 日本機械学会基準, 統計的疲労試験方法, JSME S 00-2,(1994), pp.27-37, 日本機械学会.

(27) 大野豊, 磯田和男, 新版数值計算ハンドブック, (1990), pp.778-780, オーム社.

(28) 小橋優司, 末永剛, 竹村憲太郎, 高松淳, 小笠原司, “頭部装着型視線計測装置のための自然特徵点を用いた三次元 注視点推定”，映像情報メディア学会技術報告, Vol.33, No.45 (2009), pp.5-10.

(29) 大本浩司，高橋励他，“事象関連電位によるメンタルワークロードの評価”，人間中心設計，Vol5，No.1 (2009), pp.29-37.

(30) 芳賀繁, 水上直樹, “日本語版 NASA-TLXによるメンタルワークロード測定-各種室内実験課題の困難度に対するワ ークロード得点の感度”, 人間工学, Vol.32, No.2 (1996), pp.71-79.

(31) 川村涼, 児珠大輔, 国井哲也, 佐藤由美, 目加田慶人, 阿山みよし, 春日正男, “自動車運転時の有効視野に対する視 聴覚負荷の与える影響”, 映像情報メディア学会技術報告, Vol.24, No.41 (2000), pp.7-12. 